\title{
The determinant of bank interest rates spreads in Ghana
}

\author{
Ransford Quarmyne Churchill ${ }^{1}$, Collins Owusu Kwaning ${ }^{2}$, Owusu Ababio ${ }^{2}$ \\ ${ }^{1}$ Department of Accountancy, School of Business and Management Studies, Accra Polytechnic \\ ${ }^{2}$ Department of Liberal Studies, School of Business and Management Studies, Accra Polytechnic Ghana
}

\section{Email address:}

ransfordchurchill@yahoo.co.uk (R. Q. Churchill)

\section{To cite this article:}

Ransford Quarmyne Churchill, Collins Owusu Kwaning, Owusu Ababio. The Determinant of Bank Interest Rates Spreads in Ghana. International Journal of Economic Behavior and Organization. Vol. 2, No. 4, 2014, pp. 49-57. doi: 10.11648/j.ijebo.20140204.11

\begin{abstract}
In Ghana, there is a widespread perception that interest rate spread is too wide. Banks, on the other hand, had justified the wide interest rate spread on the basis of some economic variables that affect the banks. The purpose of this paper is to examine the determinants of the bank interest margin in Ghana. This paper therefore examines the determinants of banking sector interest rate spreads in Ghana. Based on the availability of data, the paper focused on some banking industry-specific and macroeconomic determinants of (IR) spread. This study used exploratory and explanatory approaches. The exploratory methodology was used to identify the factors affecting determination of interest rate spreads and an explanatory approach was employed to establish how the factors affect the determination of interest spread in Ghana. The study found that factors affecting the determination of interest rate spread in Ghana are GDP, Exchange Rate, Prime Rate, Treasury Bill Rate, Liquidity, Overhead Costs, Loan Loss Provisioning and Profit Margin.
\end{abstract}

Keywords: Interest Rate Spread, Treasury Bills, Bank of Ghana, Exchange Rate, Prime Rate, Liquidity

\section{Introduction}

One of the expected benefits of financial liberalization and deepening of the financial sector is the narrowing of the interest rate spread which is the difference between the interest rate charged to borrowers and the rate paid to depositors. This is predicated on the understanding that liberalization enhances competition and efficiency in the financial sector. Thus, a wide deposit-lending interest rate spread could be indicative of banking sector inefficiency or a reflection of the level of financial development (Folawewol and Tennant, 2008). Embedded in the spread, is the information on the efficiency of financial intermediation, profitability, monetary policy impact, among others. An analysis of bank interest rate spreads is therefore central to the understanding of the financial intermediation process and the macroeconomic environment in which banks operate.

The issue of Bank interest spreads in Ghana has generated considerable public debate recently as the gains of the macro stability have not been translated into significantly declining interest rate spreads. According to Bawumia et al (2005), interest rate spreads within the Ghanaian banking industry are among the highest in Africa. Ghana ${ }^{e c}$ s experience with the aim of liberalizing the interest rates through financial sector reforms has rather shown a widening interest rate. The period of liberalization has been characterized by high implicit costs with tight monetary policy achieved through increased reserves and cash ratios (Bawumia et al, 2005).

While the McKinnon and Shaw theoretical framework posits low real interest rates is a disincentive to savings, thus the financial sector should be liberalized for real interest rates to increase, thereby reversing the disintermediation process and increasing the availability of credit, the models of Stiglitz and Weiss (1981) assert interest rates cannot be the main allocator of credit as it can be used as a screening device between high risk and low risk borrowers who rather have the potentials to invest. More currently, there is the growing belief that interest rates must be low for private investments to be boosted. It thus appears there is some level of inconsistency in the linkage between interest rates and the demand for credit.

The problems associated with high interest rate in Ghana have led to industry stakeholders suggesting for reduction in the interest rate in Ghana. The failure to reduce the interest rate spreads are known to emerge from the following problems: 
- Lack of changes in the structure and institutional behaviour of the banking system shown by concentration, the conditions of free entry and competitive pricing.

- High reserve requirements, which act as implicit financial tax. While reserve requirements may be designed with the aim of protecting depositors, the availability of a pool of resources allows for financing high fiscal deficits through the implicit financial tax, creating an environment that can promote high inflation and persistent high intermediation margins.

- Adverse selection and adverse incentive (moral hazard) effects, which could result in mounting non-performing loans and provision for doubtful debts.

- High operational costs have also been found to be a source of persistent and wide intermediation spreads in developing countries. Operational costs reflect variations in cost of capital, employment, and wage levels. Inefficiency in bank operations may also be shifted to bank customers through wide margins.

- The cost of capital that banks hold to cushion themselves against risks is relatively more expensive than debt because of taxation and may lead to high spreads.

- Macroeconomic instability and the policy environment may also affect the pricing behaviour of commercial banks.

This paper is attempts at addressing the issue of the determinants of interest rate spreads in Ghana empirically, through income statement and balance sheet analysis as well as econometric estimations.

\section{Literature Review}

\subsection{Overview of Interest Rate Spread}

Over the past few years, interest rate spread of commercial banking system has caught researchers ${ }^{\text {ee }}$ attention throughout the world. As financial intermediaries, banks play a crucial role in the operation of most economies. The efficiency of financial intermediation can affect economic growth. Fundamentally, financial intermediation affects the net return to savings and the gross return to investment (Demirguc-Kunt \& Huizinga, 1999).

Demirguc-Kunt and Huizinga again report that the bank interest rate spread is positively influenced by the ratio of equity to lagged total assets, by the ratio of loans to total assets, by the ratio of overhead costs to total assets, by inflation rate, and by the short-term market interest rate in real terms. The ratio of non-interest earning assets to total assets, on the other hand, is negatively related to the bank interest margin.

Another school of taught is concerned with the adjustments of bank interest rates to the market interest rate. These studies show that, in the long run, one cannot reject the hypothesis that bank interest rates follow the market interest rate in a one-to-one basis, that is, there is full adjustment to changes in the market interest rate. In the short-run, though, the departures of bank interest rates from the market interest rate are relevant and there is some evidence that adjustments towards the long run equilibrium are asymmetric, i.e the adjustment varies according to whether one observes positive or negative unbalances.

According to the prior researchers, interest rate spread (IRS) is described in several ways. IRS is a key variable in the financial system when it is too large. It is generally regarded as a considerable impediment to the expansion and development of financial intermediation. This often discourages potential savers with low returns on deposits and limits for financing potential borrowers, thereby reducing feasible investment opportunities and the potential growth of the economy (Barajas, Steiner, and Salazar, 1999). Robinson (2002) highlights that loan rates charged by commercial banks can be separated into two major components. One is the interest rate paid to depositors and the other rate is risk premium. IRS can also be defined as the difference between average interest rate earned on interest earning assets (loans) and average interest rate paid on deposits (Jayaraman and Sharma, 2003).

The magnitude of interest rate spread is dependent on the determinants or factors which determine the spread. Such determinants include inflation, growth of output and money market real interests which are all macroeconomic variables. Jayaraman and Sharma (2003) recognized the reasons for high IRS as lack of adequate completion, scale diseconomies due to small size of markets, high fixed and operating costs, high transportation costs of funds perceived market risks and the risk profile of the bankers. Khawaja and Din (2007) examine to what extent macro-economic variables influence the IRS. The central bank influences the yield on treasury bills of a country, which in turn affects the deposit and lending rates.

There is some evidence of price rigidity in local deposit markets with decrease in deposit interest rates being more likely than increases in these rates in the face of changes in the market interest rate (Hannan and Berger, 1991). One reason for such behavior is market concentration: banks in concentrated markets were found to exacerbate the asymmetric adjustments (Neumark and Sharpe, 1992). The same sluggishness has been observed for the loan interest rate. Cottarelli and Kourelis (1994) apply a two-step approach to investigate the reasons for the stickiness of bank lending rates for a sample of countries. In the first step, the impact multipliers of changes in the market interest rate are calculated for each country in the sample. In the second step, such impact multipliers are regressed against a large set of explanatory variables controlling for cross-country differences in the competition within the banking system, in the extent of money market development of the financial system.

The market or industry-specific determinants of spreads 
included account for the impacts of the structure and development of the banking sectors in the Ghana, prescribed reserve requirements, and economies/diseconomies of scale, as determined by market size. The structure and development of the banking sector is captured using two proxies- the Bank/GDP ratio and RealPer Capita GDP. As in Demirguc-Kunt and Huizinza (1998) the bank/GDP ratio (BANKDEV) is calculated as the total assets of commercial banks divided by current GDP. This ratio reflects the overall level of development of the banking sector, and the level of inter-bank competition in well-developed banking sectors. This ratio is expected to have a negative correlation with the dependent variable, as an improvement in the level of banking sector development and competition should force down banking sector interest rate spreads (IRS). Real per capita GDP (RGDPpc) should have a similar effect on IRS, as it is as a general index of economic development, and should therefore reflect „differences in banking technology and the mix of banking opportunities ${ }^{\text {ee }}$ (Demirguc-Kunt and Huizinga, 1998).

An argument has been made to explain the failure of spreads in developing countries to converge to international levels even after financial liberalization, suggests that high interest rate spreads in developing countries will persist if financial sector reforms do not significantly alter the structure within which banks operate (Chirwa and Mlachila, 2004). This structure refers to the market/industry and macroeconomic environment in developing countries. The market-specific determinants of commercial bank interest rate spreads highlighted in the literature typically include lack of adequate competition in the banking sector and consequent market power of commercial banks, the degree of development of the banking sector, and explicit and implicit taxation - such as profit taxes and reserve requirements. Cross-country studies have also established that interest rate spreads for Banks tend to fall as institutional factors improve. Such factors include the efficiency of the legal system, contract enforcement, and decreased levels of corruption, which are all critical elements of the basic infrastructure needed to support efficient banking.

\subsection{Economy of Ghana}

The economy of Ghana, Africa, has a diverse and rich resource base, and as such, has one of the highest GDP per capita in Africa. Ghana is one of the top-ten fastest growing economies in the world, and the fastest growing economy in Africa. Ghana remains somewhat dependent on international financial and technical assistance as well as the activities of the extensive Ghanaian diaspora. Gold, timber, cocoa, diamond, bauxite, manganese, and many other exports are major sources of foreign exchange. An oilfield which is reported to contain up to 3 billion barrels $\left(480 \times 10^{6} \mathrm{~m}^{3}\right)$ of light oil was discovered in 2007 Oil exploration is ongoing and, the amount of oil continues to increase. The six (6) main industries that contribute strongly to the economy and therefore the GDP of Ghana are Agriculture, Mining, Petroleum, Manufacturing, Energy and Services which include tourism.

The domestic economy revolves around services, which accounts for $48.5 \%$ of GDP and employs $28 \%$ of the work force. On the negative side, public sector wage increases and regional peacekeeping commitments have led to continued inflationary deficit financing, depreciation of the Cedi, and rising public discontent with Ghana's austerity measures. Furthermore, according to the World Bank, Ghana's per capita income has barely doubled over the past 45 years. Even so, Ghana remains one of the more economically sound countries in all of Africa. The country has, since July 2007, embarked on a currency re-denomination exercise, from Cedi $(\phi)$ to the new currency, the Ghana Cedi $(\mathrm{GH} \phi)$. The transfer rate is 1 Ghana Cedi for every 10,000 Cedis. Ghana has embarked upon an aggressive media campaign to educate the public about what re-denomination entails. Value Added Tax is a consumption tax administered in Ghana. The tax regime which started in 1998 had a single rate but since September 2007 entered into a multiple rate regime. In 1998, the rate of tax was $10 \%$ and amended in 2000 to $12.5 \%$.

\subsection{Interest Rates and Monetary Policy}

The 2002 Bank of Ghana Act sets the stage for the transition to inflation targeting by recognizing the independence of the central bank to set interest rates. The Act mandates that the primary objective of the Bank of Ghana's monetary policy is price stability (in the law, growth and exchange rate stability are secondary policy objectives). The Monetary Policy Committee (MPC) was created in 2002 and was charged with the formulation of monetary policy. Formal inflation targeting started in May 2007 , but in the preceding period the Bank of Ghana developed the institutional capacity necessary for implementing the inflation targeting regime (Addison, 2008), and during this transition period Ghana's central bank moved away from the traditional monetary policy framework that was focused on targeting a monetary aggregate, towards analyzing a broader range of indicators to assess its monetary policy stance.

The shift to inflation targeting was preceded by other important changes in the financial system, including the liberalization of exchange and interest rate controls, and the partial opening of Ghana's external capital account, which allowed for the first time foreigners to participate in the longer-end of the domestic bond market, while Ghanaian residents would be able to hold foreign currency bank accounts. The exchange rate is floating but has remained remarkably stable against the U.S. dollar during the past year. Domestic capital markets have also started to develop, which has brought new investment options to the Ghanaians (such as stocks, treasury bills and bonds). Furthermore, new payment instruments, such as credit and debit cards, have started making inroads in the Ghanaian economy and are expected to reduce the demand for cash in daily transactions, while modern payment technology and electronic banking 
are expected to expand banking services to the rural communities deprived of such options (see, for instance, Buchs and Mathisen (2005) and International Monetary Fund (2011) for discussion on Ghana ${ }^{\text {ee }}$ financial system).

Such changes in the financial system often lead to instability in the demand for money and can cause important shifts in the monetary transmission mechanism, complicating monetary policy implementation. In particular, when a central bank in such instances continues to target a money aggregate, such as reserve money, policy effectiveness resting on the stability of the monetary transmission mechanism and the constancy of money velocity may be compromised due to the loss of stability in reality. An important argument, therefore, for moving to inflation targeting, and adopting a short-term interest rate as the operating target, is that such a regime does not depend on the stability of money demand (for instance, Mishkin, 1999). When the relationship between money and inflation is subjected to unexpected shifts, as is often the case when the financial sector goes through significant reforms, monetary targets lose their transparency and cannot accurately signal the underlying stance of monetary policy.

Through open market operations, the central bank is able to manage liquidity in the interbank market and thereby the cost of borrowing in this market. In the long-run, therefore, the interbank interest rate is expected to reflect the Monetary Authorities' Policy stance. In the absence of expected liquidity injections or leakages by the central bank, the bankes end-of-day settlement needs are symmetrically distributed around a zero mean (see, for instance, Henckel, Ize, and Kovanen (1999). Assuming that the central bank leaves the money market short in the end of the day (in the model denoted by the term $\mathrm{u}$ ), this will increase the demand for bank reserves at the central bank.

\subsection{Theories of Interest Rates}

Interest rate is the price of money that is the amount of interest paid per unit of time expressed as a percentage of the amount borrowed. The cost of borrowing money, measured in cedis, per year per cedis, borrowed, is the interest rate. Interest rates differ mainly in term/maturity that is the length of time for repayment and liquidity that is quick conversion of assets to funds. When maturity and liquidity together with other factors are considered, many different financial instruments and so many different interest rates will emerge (Anyanwu, 1997). Interest rates can either be nominal or real. Nominal interest rate can be measured in naira terms, not in terms of goods. The nominal interest rate measures the yield in cedi per year, per cedi invested while the real interest rate is corrected for inflation and is calculated as the nominal interest rate minus the rate of inflation (Pandey, 1999). Anyanwu (1990) explicated the following interest rate theories: (a) the classical theory, (b) the loanable funds theory, (c) the Keynesian theory and (d) the modern theory of interest or the Hicks-Hanson IS - LM Model.

\subsubsection{The Loanable Funds Theory}

This is a flow theory that determines the interest rate by the interaction of demand for and supply of loanable funds or credit. It involves the linking of the interest rate with non-saving, investment and hoarding of funds sourced from government, businessmen and consumers, on the demand side with saving, dishoarding and bank money on the supply side from private individuals and corporate bodies. Hansen asserted that the loanable funds theory like the classical and the Keynesian theories of interest are indeterminate unless the income level is already known.

\subsubsection{Keynesian Liquidity Preference Theory}

Keynesian liquidity preference theory is a stock theory. The theory determines the interest rate by the demand for and supply of money. It emphasizes that the rate of interest is a purely monetary phenomenon as distinct from the real theory of the classics. It is a stock analysis because it takes the supply of money as given during the short run and determines the interest rate by liquidity preference or demand for money.

\subsection{Interest Rate Spreads}

Interest rate spread is defined by market microstructure characteristics of the banking sector and the policy environment. In differentiating between the pure spread and the actual spread Ho and Saunders (1981) observe that pure spread is a microstructure phenomenon, influenced by the degree of bank risk management, the size of bank transactions, interest rate elasticity and interest rate variability. Zarruk (1989), considering risk management by the bank, found that risk-averse banks operate with a smaller spread than risk-neutral banks, while Paroush (1994) explains that risk aversion raises the bank's optimal interest rate and reduces the amount of credit supplied. Actual spread, which incorporates the pure spread, is in addition influenced by macroeconomic variables including monetary and fiscal policy activities. Hanson and Rocha (1986) emphasize the role of direct taxes, reserve requirements, cost of transactions and forced investment in defining interest rate spread.

\subsection{Empirical Studies on Interest Rate Spread}

Brock and Franken (2003) studies interest rate spread in Chile, showing that that the influence of industry concentration, business cycle variables, and monetary policy variables on interest rate spreads differs markedly depending on whether the spreads are computed from balance sheet data or from disaggregated loan and deposit data. Gambacorta (2004) studies factors explaining cross-sectional differences in bank interest rates of Italian banks by considering both micro and macroeconomic factors. The variables considered include, loan and deposit demand, operating cost, credit risk and interest rate volatility, impact of monetary policy through changes in policy rates and reserve requirements and the structure of the industry. Results showed that interest rates on short 
term lending of liquid and well capitalized banks react less to monetary policy shocks.

In addition, banks that predominantly lend for long term do not change their interest rates more frequently as those whose lending is largely for short term. Bank size was found to be irrelevant in influencing interest rate margins. According to Gambacorta (2004), lending rates have a positive relationship with real GDP and inflation. An increase in real economic activity makes projects that would otherwise appear unfeasible become profitable when discounted to the present. The increase in economic activity therefore increases demand for credit. An increase in real GDP and inflation are negatively related with deposit rates. When the economy is booming, it pushes up demand for deposits and therefore banks have no incentive to increase deposit rates.

Demirguç-Kunt and Huizinga (1999) examines interest spreads in a cross-country set up using data covering commercial banks from 80 countries across the world. The study finds that differences in interest margins and bank profitability are explained by several factors such as bank characteristics, macroeconomic variables, explicit and implicit bank taxation and deposit insurance regulation. After controlling for factors such as differences in bank activity, the extent to which banks are leveraged, and the macroeconomic environment, they show that lower interest margins and lower profits are associated with larger banks asset to GDP ratio and a lower market concentration ratio. Additionally, foreign banks are associated with higher interest margins and higher profits compared to local banks in developing countries while the opposite is true for developed countries. Mannasoo (2012) investigates the role of the recent global financial crisis on interest spreads in Estonia. The approach follows works of Ho and Saunders (1981) in which the spread is decomposed into a pure spread and the remaining component that is explained by market structure, regulation and idiosyncratic bank factors. The pure spread is explained by the degree of bank risk aversion and the market structure of the banking sector. The volatility of money market interest rates is found to have a long-run impact on the spread. Other factors that drive the interest margins are the regulatory variables, efficiency of banks and bank-portfolio effects. Credit risk was found to play a minimal role while higher bank liquidity was associated with lower interest margin.

It has been observed that the financial systems in developing countries exhibit larger IRS than those in developed countries (Hanson and Rocha 1986, Morris et al. 1990, Fry 1995, Randall 1998, Barajas, Steiner and Salazar 2000, Saunders and Schumacher 2000). Researchers have attributed the existence of high IRS in developing countries to several factors, such as high operating costs, financial repression, lack of competition and market power of a few large dominant banks enabling them to manipulate industry variables including lending and deposit rates, high inflation rates, high risk premiums in formal credit markets due to widely prevailing perception relating to high risk for most borrowers, and similar other factors (see, Agu 1992,
Aryeetey, Hettige, Nissanke and Steel 1997, Barajas et al. 1999, Brock and Rojas-Suarez 2000, Smirlock 1985, Mujeri and Islam 2008).

\section{Methodology}

\subsection{Research Design}

This study used exploratory and explanatory approaches. The exploratory methodology was used to identify the factors affecting determination of interest rate spreads. Saunders et al (2007) described exploratory studies as a valuable means of finding out, seeking new insights, asking questions and assessing a phenomenon in a new context. An explanatory approach is employed to establish how the factors affect the determination of interest spread in Ghana. Saunders et al (2007) indicated that explanatory studies establish a causal relationship between variables. The case study design is employed to find answers to the afore-mentioned research questions. The justification for this method is that it generates answers to questions such as why, what and how the factors affect interest rate spread. A case study strategy can be used in exploratory and explanatory research (Saunders et al, 2007).

\subsection{Population and Sampling}

The study population was banks in Ghana who were operating as at the time of the research. Due to resource constraints, purposive sampling technique was used for this study. This sampling method is a form of non-probability sampling in which decisions concerning the individuals or sources of data to be included in the sample are taken by the researcher, based upon a variety of criteria. Some types of research design necessitate researchers taking a decision about the individual participants or sources of data which would be most likely to contribute appropriate data, both in terms of relevance and depth (Oliver, (2006).

\subsection{Method of the Study}

Secondary data was used in this study. Before estimation procedure, data on Interest Rates Spread, Real GDP per capita, Inflation, Exchange Rate, Prime Rate and Treasury Rate from 2004 to 2012 were obtained from the Bank of Ghana and the Ghana Statistical Service. Other relevant data were also obtained same sources on liquidity, overhead cost, loan loss provisioning and profit margins of the banks.

\subsection{Model Specification and Data Analysis}

The determinants of interest rate spread of the banks were identified using Multiple Regression Model Pearson's Correlation with the help of Microsoft Excel Spreadsheet. Interest Rate Spread was taken as the dependent variable while the independent variables which influence interest rate spread were taken as GDP, inflation, exchange rate, policy rate, treasury rate, liquidity, overhead cost, loan loss 
provisioning and profit margin. The empirical estimation of equation is carried out using Pearson Correlation which was used in determining the relationship between the dependent variable and independent variables. The relations between IRS and the various Economic Indicators can be expressed by the Multiple Linear Models below:

$$
\begin{aligned}
& y=b_{0}+b_{1} x_{1}+b_{2} x_{2}+\ldots+b_{p} x_{p}+\varepsilon \\
& y=b_{0}+\sum_{i} b_{i} x_{i}+\varepsilon
\end{aligned}
$$

$\mathrm{i}=1,2, \ldots . . \mathrm{p}$

Where

y -Dependent variable (predicted by a regression model)

$\mathrm{p}$-Number of independent variables (number of coefficients)

$\mathrm{x}_{\mathrm{i}}(\mathrm{i}=1,2, \ldots \mathrm{p})$-ith independent variable from total set of $\mathrm{p}$ variables $b_{i}(i=1,2, \ldots p)$ - ith coefficient corresponding to $x i$ $\mathrm{b}_{0}$ - intercept (or constant)

$\varepsilon-$ (Epsilon) error term

\section{Results and Discussion}

\subsection{Factors of Interest Rate - Economic Indicators}

In order to ascertain the factors affecting interest rate in Ghana, the interests from 2004 to 2012 were correlated with individual factors and these GDP, Inflation, Exchange Rate, BoG Prime rate and T-Bill Rate covering 2004 to 2012. The purpose of this was to help find whether the any relationship between interest rate and the above factors. The table below illustrates the interest rate and the selected factors for 2004 to 2012

Table 4.1. Descriptive Statistics of the Variables

\begin{tabular}{lllllll}
\hline \multicolumn{2}{l}{ Economic Indicators } & & & & \\
\hline Year & Lending Interest Rate & GDP & Inflation (Average period & Exchange Rate (GHS to USD) & BoG Prime Rate & T-Bill Rate \\
\hline 2004 & 28.8 & 5.3 & 12.6 & 0.9 & 18.5 & 16.4 \\
2005 & 25.0 & 6.0 & 15.1 & 0.9 & 15.5 & 11.4 \\
2006 & 23.3 & 6.1 & 10.2 & 0.9 & 12.5 & 9.9 \\
2007 & 24.2 & 6.5 & 10.7 & 0.9 & 13.5 & 10.3 \\
2008 & 27.3 & 8.4 & 16.5 & 1.1 & 17 & 23.2 \\
2009 & 32.8 & 4.0 & 19.3 & 1.4 & 18.0 & 22.4 \\
2010 & 27.6 & 7.7 & 15.8 & 1.5 & 13.5 & 11.9 \\
2011 & 18.2 & 14.4 & 8.7 & 1.8 & 12.5 & 23.1 \\
2012 & 25.7 & 7.1 & 9.2 & 1.9 & 15.0 & 23.1 \\
\hline
\end{tabular}

Source: Field work, 2014

From the table above (Table 4.1) Pearson ${ }^{\text {ee }}$ Correlation model, thus relationship between lending interest rate and the economic factors was employed with help of Microsoft Excel Spreadsheet. The results from the correlation operations are given in the table below.

Table 4.2. Correlation between interest rate and macroeconomic factors

\begin{tabular}{lll}
\hline Dependent Variable & Independent Variables & Correlation \\
\hline LIR & GDP & -0.80 \\
LIR & INFL & 0.81 \\
LIR & EXR & 0.20 \\
LIR & PRIMR & 0.80 \\
LIR & TBIL & 0.09 \\
FINAL OUTCOME & & 1.10 \\
\hline
\end{tabular}

Source: Field work, 2014

\subsection{Gross Domestic Products}

From the Table 4.2, it can be seen that the relationship between lending interest rate and GDP is -0.80 (negative relationship). This implies that the banks do not necessary base their lending interest rate on GDP. This is evident in Table 4.1, thus in 2004 GDP increased from 5.3\% to $6.0 \%$ in 2006 and at the same time the banks ${ }^{\text {ee }}$ lending rate reduced from $28.8 \%$ to $26.0 \%$, showing a negative relationship. The same indication is shown in 2007 to 2012 .
It is important to state that the above findings are very opposite to the idea that the effect of real GDP on interest rates is essentially equivalent to the effect of domestic economic growth on interest rates, according to the economist Steven M. Suranovic. A risen in GDP, according to Suranovic, will lead to a rise in interest rates, as demands for funds increase. This is because when a country's economy is booming, more investors will be investing money into that economy. This would increase demand for funds which subsequently lead to lenders asking for higher interest rates. Secondly, as an economy booms, inflation will generally increase. This will lead to an increase in the interest rate commanded by lenders, so as to keep pace with inflation.

\subsection{Inflation}

The results shown in Table 4.2 indicate that the correlation between lending interest rate and inflation rate is 0.81 (positive). This outcome implies that when there is an increase in the level of Inflation, there was an increase in Bank Lending Rate and vice versa. This is evident in Table 4.1 where the Inflation Rate decreased in from $15.1 \%$ in 2005 to $10.2 \%$ in 2006 resulting in an decrease in Lending Interest Rate of $26.0 \%$ to $23.3 \%$ in the same period. However, in 2007 when there was an increase in Inflation 
from $10.2 \%$ in 2006 to $10.7 \%$ in 2007 , the same trend was witnessed with regards Lending Interest Rate. This trend continued till 2010 when Inflation dropped (15.8\%) and further dropped in $2011(8.7 \%)$ resulting in decrease in Lending Interest Rate of $27.6 \%$ in 2010 and further decreased to $18.2 \%$ in 2011. Likewise, when Inflation increased in 2012 (9.2), it attracted an increase in Lending Interest Rate of $25.7 \%$ in the same year.

Inflation as a rise in the general level of prices of goods and services in an economy over a period over a period of time can be said to have an impact on Lending Interest Rate. This means that when the general price level rises, each unit of currency buys fewer goods and services. Consequently, inflation also reflects erosion in the purchasing power of money, thus a loss of real value in the internal medium of exchange and unit of account within the economy. Lower interest rates put more borrowing power in the hands of consumers and when consumers spend more, the economy grows thereby creating natural inflation. If the Central Bank decides that the economy is growing too fast that demand will greatly outpace supply, then it can raise interest rates, slowing the amount of cash entering the economy.

\subsection{Exchange Rate}

With regards to the relationship between interest rate and inflation, the results as shown Table 4.2 indicate that the relationship is positive $(0.20)$. This outcome means that increases in exchange rate will affect lending rate to increase and vice versa. Implying that the value of one country's currency in terms of another currency, which is opened to a wide range of different types of buyers and sellers where currency trading is continuous. It must be noted that that interest rates, inflation and exchange rates are all highly correlated. By manipulating interest rates, central banks exert influence over both inflation and exchange rates, and changing interest rates impact inflation and currency values. Higher interest rates offer lenders in an economy a higher return relative to other countries. Therefore, higher interest rates attract foreign capital and cause the exchange rate to rise. The impact of higher interest rates is mitigated, however, if inflation in the country is much higher than in others, or if additional factors serve to drive the currency down. The opposite relationship exists for decreasing interest rates - that is, lower interest rates tend to decrease exchange rates.

\subsection{BoG Prime Rate and Treasury Bill Rate}

From Table 4.2, it is shown that the relationships between interest rate and BoG prime rate, and Treasury bill rate are 0.80 and 0.09 respectively. From Table 4.1, in 2005 to 2006 there were reductions in the prime and Treasury bill rate, banks followed suit by reducing their lending rate from $28.8 \%$ in 2004 to $26.0 \%$ in 2005 . These are also evident in the years 2007 to 2012. This means that the Central Bank as the determiner of prime rate and treasury bill rate, sets the base rate and treasury bill rate and when these happen, the banks are expected to follow suit. However the banks' decision to follow suit is also informed by other factors such as inflations, exchange rate and banks' own factors.Overall Correlation Result

The mean average of the various correlations is determined using the model below:

$$
L I R=\frac{G D P+I N F L+E X R+P R I M R+T B I L}{N}
$$

Where:

LIR is the Lending Interest Rate

GDP is the Gross Domestic Product

INFL is the inflation (year-on-year)

EXR is the Exchange Rate

PRIMR is the BoG Prime Rate

TBIL is the Treasury Bill

From the above model, the mean average of the correlations between $L I R$ and $G D P+I N F L+E X R+$ PRIMR + TBIL is calculated as follows:

$$
\begin{aligned}
& L I R=\frac{-0.8+0.81+0.20+0.80+0.09}{5} \\
& L I R=0.22
\end{aligned}
$$

From the calculations above, it is shown that the correlation between LIR and GDP + INFL + EXR + PRIMR + TBIL is 1.1 which represents a positive relationship, thus an increase in the economic factors such as GDP, inflation, exchange rate, prime rate and treasury rate cause interest rate to rise as well. This means that interest rate of the banks are affected by GDP, inflation, exchange rate, prime rate and treasury bill rate.

\subsection{Interest Rate as a Relation between the Various Economic Indicators using Multiple Regression Model}

Using the model (1a) defined above resulted in the following Statistical Relations:

Table 4.3. Regression Statistic

\begin{tabular}{ll}
\hline Multiple $\mathrm{R}$ & 0.99 \\
$\mathrm{R}$-Square $\left(\mathrm{R}^{2}\right)$ & 0.98 \\
Adjusted $\mathrm{R}^{2}$ & 0.94 \\
Std. Error & 0.97 \\
Observation & 9 \\
\hline
\end{tabular}

Where $\mathrm{R}$ is the Correlation between interest rate and all the other factors combined indicating a strong positive relation. The $\mathrm{R}^{2}$ (the coefficient of determination) usually shows how well the model predicts or forecasts future events. In table 4.3 , the $\mathrm{R}^{2}$ is $98 \%$ indicating that $98 \%$ of changes in the interest rate is as a result of changes in the economic indicators as shown in table 4.3 above and also indicates the model indeed predicts well. Using the multiple regression model, as defined above, between interest rate and the other economic indicators resulted in 
an intercept of 12.53 which was calculated using the E-views and the corresponding slops for the various Economic indicators as shown in table 4.4. So given an intercept of 12.53 , it implies that the interest rate is also 12.53 if the slope is zero.

This can be expressed mathematically as

$$
y=12.53+(-0.71 m+0.43 n+3.21 o+0.69 p-0.09 q)+\varepsilon
$$

Where

$\mathrm{y}=$ Interest Rate

Table 4.4. Economic Indicators and their Slops

\begin{tabular}{ll}
\hline Parameter & Coefficients \\
\hline GDP(m) & -0.71 \\
Inflation(Period average)(n) & 0.43 \\
Exchange Rate (GHS to USD)(o) & 3.21 \\
BoG Prime Rate (p) & 0.69 \\
T-Bill Rate (q) & -0.09 \\
\hline
\end{tabular}

\section{Conclusions}

Generally, interest rate spreads in Ghana still remain high and continues to present a subject of debate for stakeholders in the banking and business sectors in the economy. The study to this end conclude that the factors determining this high interest rate spreads are GDP, inflation, exchange rate, prime rate, treasury bill rate, liquidity position of banks, overhead costs, loan loss provisioning and profit margins of the banks. It must however be stated that apart from these factors there are others that this study could not cover.

\section{References}

[1] Anyanwu J. C. (1990). Monetary Economics Theory Policy and Institutions Hybrid Publishers Ltd. Pp 247- 274

[2] Barajas, R. S and Salazar (1999). Foreign Investment in Colombiae's Financial Sector of IMF working Paper. Vol. 99. Pp 9.

[3] Bawumia, M., Belnye, F. and Ofori, M. E. (2005) The Determination of Bank Interest Spreads in Ghana: An Empirical Analysis of Panel Data, Working Paper, Monetary Policy Committee, Bank of Ghana.

[4] Brock, P. and Franken, H. (2003). Measuring the Determinants of Average and Marginal Bank Interest Rate Spreads in Chile, 1994-2001, Working Papers UWEC2003-25, University of Washington, Department of Economics.

[5] Brock, Philip and Franken, Helmut (2003). Measuring the Determinants of Average and Marginal Bank Interest Rate Spreads in Chile, 1994-2001. www.econ.washington.edu/user/plbrock/ChileSpreads09160 3.pdf

[6] Buchs T.D and Mathisen (2005). Competition and Efficiency in Banking: Behavioral Evidence from Ghana. Pp 1-25.
[7] Caprio, G., Jr. 1996. "Banking on financial reform? A case of sensitive dependence on initial conditions". In G. Caprio, Jr., I. Atiyas and W.J. Hanson, eds., Financial Reform: Theory and Experience. New York: Cambridge University Press.

[8] Chirwa E.W. and Mlachila (2004). Financial Reforms and Interest Rate Spreads in Commercial Banking System in Malawi. Vol. 51. Pp 5.

[9] Cho, Y.J (1988). The Effect of Financial Liberalization on the Efficiency of Credit Allocation: Some Evidences from South Korea. Journal Development Economics. Vol. 29. Pp. 101-110.

[10] Cottarellic, C. and Kourelis A. (1994). Financial Structure, Bank Lending Rates and the Transmission Mechanism of Monetary Policy. Pp 15-20.

[11] Demirguc-Kunt, A. and Huizinga, H. (1998) Determinants of Commercial Bank Interest Margins and Profitability: Some International Evidence, World Bank Economic Review, Vol. 13 No. 2, pp. 379-408.

[12] Fry, M. 1995. Money, Interest, and Banking in Economic Development, Second Edition. Baltimore: Johns Hopkins University Press.

[13] Gelbard, Enrique and Pereira Leite, Sergio (1999). Measuring Financial Development in Sub-Saharan Africa. IMF Working Paper, pp. 99 - 105.

[14] Hannan, T.H and A.N. Berger (1991). The Rigidity of Prices: Evidence from the Banking Industry. Vol. 81. Pp 938-983

[15] Ho T.S.Y and Saunders. (1981). The Determinants of Bank Interest Margins: Theory and Empirical Evidence. Pp. $15-58$.

[16] Ho, T. and Saunders, A. (1981). The Determinants of Bank Interest Margins: Theory and Empirical Evidence, Journal of Financial and Quantitative Analysis, Vol. 16, No. 4, pp. 581- 600 .

[17] Ize A. Kovanen and Henckel T. (1999). Central Banking without Central Bank Money. Pp 23-35

[18] Jayaraman, K. and Sharma, R. (2003). Determinant of Interest Rate Spread in the Pacific Island Countries: Some Evidences from Fiji. Pp. 8-9

[19] Khawaja and M. Din (2007). Determinants of Interest Rate Spreads in Pakistan- the Pakistan Development Review. Vol. 46. Pp 129-143

[20] Mishkin S. Frederic (1999). Financial Consolidation: Dangers and Opportunities. Journal of Banking and Finance. Vol. 23. Pp. 675-691.

[21] Nuemark, David and Sharpe (1992). Market Structure and Nature of Price Rigidity: Evidence from the Market for Consumer Deposits. MIT Press, Vol. 107. Pp 657-737.

[22] Pandey I.M. (1999) Financial Management. 10th Edition. Pp 20-24.

[23] Randall, Ruby (1998). Interest Rate Spreads in the Eastern Caribbean. IMF Working Paper, pp. 59 and pp. 98.

[24] Robinson, John W. (2002). Commercial Bank Interest Rate Spreads in Jamaica: Measurement, Trend and Prospects. www.boj.org.jm/uploads/pdf/papers_pamphlets.pdf 
[25] Sologoub, Dimitry (2006). The determinants of Bank Interest Margins and Profitability: Case of Ukraine. www.bof.fi/bofit/seminar/bofcef06/sologub.pdf.
[26] Stiglitz, J. E and Weiss A. M. (1981) Credit Rationing in Markets with imperfect Information. American Economic Review. Pp 313-440 